
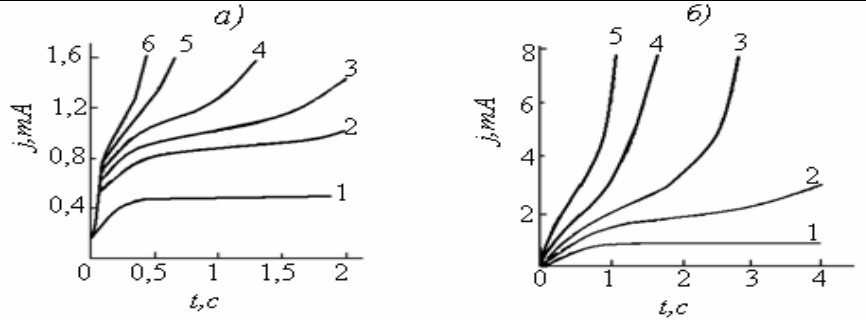

c)

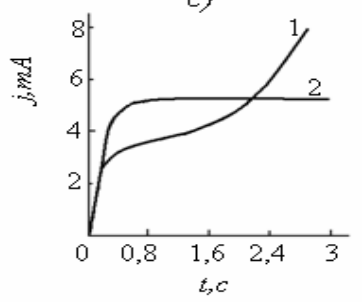

Рис.4. Экспериментальные кривые кинетики тока

с фотоприемником из GaAs при разных значениях приложенного напряжения $V$ и интенсивности оптической генерациии $F$.

Однако, неожиданным является расхождение во временных масштабах кинетики тока. Действительно, теоретически ожидается самопроизвольное возрастание за время, порядка времени жизни, тогда как экспериментально определенные значения - порядка секунды и даже десятков секунд. Это различие, на наш взгляд, связано с контактными явлениями на границе полупроводника с газоразрядной плазмой, а также свойствами полупроводников. При самопроизвольном нарастании тока происходит увеличение свечения газа и потока частиц. Действие плазменного потока на поверхность полупроводника тем сильнее, чем больше ток в системе, тем сильнее поток частиц и свечение газа в плазме.

\section{Список литературы}

1. Х.Т.Йулдашев. Фотоэлектрические усилительные процессы в сверхтонкой газоразрядной ячейке с полупроводниковым электродом. // Диссертация. 2019 г.

2. А.Н. Лодыгин, Л.М. Порцель, Ю.А. Астров Газовый разряд в аргоне и азоте при криогенной температуре в тонких зазорах. // Письма в ЖТФ. 2008.Vol. 34(14). PP. 61-66.

3. Ю.А. Астров, А.Н.Лодыгин, Л.М. Порцель Гексагональные структуры тока в системе “полупроводник-газоразрядный промежуток. // ЖТФ. 2011. Vol. 81(2). PP. 42-47.

\title{
IMPLEMENTATION OF THE COMPETENCE APPROACH IN TEACHING PHYSICS IN THE HIGHER EDUCATIONAL ESTABLISHMENT
}

\author{
DOI: $10.31618 /$ ESU.2413-9335.2019.5.62.120 \\ Kassenova Leila Galymbekovna \\ candidate of pedagogical Sciences, associate Professor \\ Saduakassov Kuanysh Bagdatovich \\ senior lecturer, Department "Information systems and technologies» \\ Kazakh University of Economics, Finance and international trade \\ The Republic of Kazakhstan, Nur-Sultan city
}

\section{ABSTRACT.}

The modern university is relevant competence-based approach in the teaching of academic disciplines, including physics. The article presents the methods of implementation of competence approach in teaching physics from the experience of the teacher.

\section{АННОТАЦИЯ.}

В современном вузе актуальным является компетентностный подход в преподавании учебных дисциплин, в том числе физики. В статье представлены способы реализации компетентностного подхода в преподавании физики из опыта работы преподавателя.

Key words: competence approach, physics, education.

Ключевые слова: компетентностный подход, физика, образование. 
The main ideas of the competence approach

At present, in the conditions of the development of a new economy, in which mobile and highly qualified human capital is becoming the main resource, a new education system is emerging in Kazakhstan. The main result of education is the readiness and ability of young people who graduate from a higher educational establishment to bear personal responsibility for their own well-being and for the well-being of society.

Important goals of education should be the development of bachelors' ability to act and be successful, the formation of such qualities as professional universalism, the ability to change the scope of activities, methods of activity at a sufficiently high level. Such personal qualities as mobility, decisiveness, responsibility, ability to assimilate and apply knowledge in unfamiliar situations, ability to build communication with other people are in demand.

The main result of the activities of an educational establishment should not be a system of knowledge and skills, but the ability of a person to act in a particular life situation.

Competence approach is a kind of attempt to bring higher education in line with the requirements of the labor market, the needs of the personality and society [1].

In the modern higher educational establishment, the competence approach in teaching academic disciplines, including Physics, is relevant. For the teacher in his practical work it is extremely important to search for psychological and pedagogical mechanisms that contribute to the formation of over-subject competencies, which include:

- ability to cast a problem, identify its statements and unknown components, select and create solutions;

- ability to follow the algorithm, create the algorithm of new activities;

- ability to see and isolate problems, make assumptions about the possible causes of physical phenomena and their consequences, see the phenomena of the material world in dynamics, put forward hypotheses and justify them;

- ability to build individual and collective activities in its full cycle, namely, set goals, analyze situations, plan and design, implement and obtain a finished product, analyze results, evaluate their actions;

- ability of self-assessment of own knowledge and skills, labor efforts;

- ability to carry out reflection of the activity.

All these competencies reflect the subjective nature of the student, the conditions for the manifestation and development of which should be created in the educational process [2].

Below are the skills that are tested in the tasks of the international research:

- recognize questions, ideas, or problems that can be scientifically researched;

- identify the information (objects, facts, experimental data, etc.) necessary to prove or confirm the findings of a scientific research;
- make a conclusion or evaluate an already made conclusion, taking into account the proposed situation;

- demonstrate communication skills; formulate conclusions and evidence reasonably and clearly;

- demonstrate knowledge and understanding of natural science concepts.

Thus, the verification of natural science literacy is aimed primarily at assessing the two main components:

1) research skills, i.e. those skills that reflect the understanding of the ways of functioning of science and its role in the modern world;

2) natural science knowledge; but here, due to the mandatory use of the "life" context, the emphasis is not on traditional educational algorithms of actions, but on the free use of minimal knowledge in the most different situations, i.e. on the free operation of the knowledge gained in new situations [3].

In the methodology of teaching physics, for example, the following types of tasks are useful for adaptation to our conditions.

1. Tasks with missing data, more precisely, tasks in which, instead of calculations or estimates, common sense is necessary. For instance:

Timur poured himself a cup of coffee, the temperature of which was about $90^{\circ} \mathrm{C}$, and a cup of cold mineral water with a temperature of about $5^{\circ} \mathrm{C}$. Both cups are the same and the volume of drinks is also the same. The temperature in the room where Timur was located was about $20^{\circ} \mathrm{C}$. What is the most likely temperature of coffee and mineral water in 10 minutes?
A) $70^{\circ} \mathrm{C}$ and $10^{\circ} \mathrm{C}$;
C) $70^{\circ} \mathrm{C}$ and $25^{\circ} \mathrm{C}$;
B) $90^{\circ} \mathrm{C}$ and $5^{\circ} \mathrm{C}$;
D) $20^{\circ} \mathrm{C}$ and $20^{\circ} \mathrm{C}$.

Well "trained" students who are not accustomed to seeing real life in educational tasks, immediately remember that drinks should come to thermal equilibrium, and choose the answer (D). However, common sense suggests that in 10 minutes a cup of almost boiling coffee usually does not cool to room temperature. Therefore, the correct answer is (A), as the most appropriate for this case.

2. Tasks for understanding the individual elements of scientific research.

3. Tasks for searching the optimal information.

For instance: The following statement emphasizes a few words. "According to astronomers, in the current century, from the planet Neptune it is possible to observe the transit of Saturn across the disk of the Sun."

What three underlined words would be most useful when searching the Internet or libraries if you need to know exactly when this transit can occur?

Answer: "Saturn /Neptune/transit".

Competence approach in teaching Physics

The implementation of the competence approach in teaching Physics is expressed in solving the following main tasks:

- Mastering the structure of activity from the perspective of the competence approach.

- Differentiation of subject content, ensuring the development of basic and advanced levels of training. 
- Development and selection of tools, methods, techniques, and use of technologies that provide an activity approach to learning.

- Creation of a simple and objective monitoring system.

\begin{tabular}{|l|l|l|}
\hline Type of activity & Forms of diagnosis & Competence \\
\hline Working with educational literature & Execution of "for compliance" tasks & Information, educational \\
\hline Doing student's independent works & Selective quiz, defense of works & Cognitive, informational \\
\hline Doing individual homeworks & $\begin{array}{l}\text { Inclusion of tasks in the scheduled re- } \\
\text { view works }\end{array}$ & Cognitive, informational \\
\hline Presentation of information work & $\begin{array}{l}\text { Demonstration of the presentation in } \\
\text { the auditorium }\end{array}$ & $\begin{array}{l}\text { Informational, communi- } \\
\text { cative }\end{array}$ \\
\hline $\begin{array}{l}\text { Monitoring the progress of the physical phenom- } \\
\text { enon, the process at home, writing a brief or de- } \\
\text { tailed report. }\end{array}$ & $\begin{array}{l}\text { Demonstration at the seminar lesson, } \\
\text { at the classes of student-teacher inde- } \\
\text { pendent work, subject decade }\end{array}$ & Cognitive, informational \\
\hline $\begin{array}{l}\text { Implementation of virtual physical experience in } \\
\text { pairs in the group, drawing conclusions }\end{array}$ & $\begin{array}{l}\text { Selective quiz, final check of the } \\
\text { work done at the end of the lesson }\end{array}$ & $\begin{array}{l}\text { Cognitive, informational, } \\
\text { communicative }\end{array}$ \\
\hline $\begin{array}{l}\text { Creative works of a research nature, as one of the } \\
\text { forms of homework }\end{array}$ & Demonstration at the seminar lesson & Cognitive, informational \\
\hline $\begin{array}{l}\text { Performing a review-feedback on the work of the } \\
\text { classmate }\end{array}$ & $\begin{array}{l}\text { Speech during mini-conferences, } \\
\text { subject decade, defense of term pa- } \\
\text { pers }\end{array}$ & $\begin{array}{l}\text { Informational, communi- } \\
\text { cative }\end{array}$ \\
\hline Preparation of term papers & Presentation, defense & $\begin{array}{l}\text { Cognitive, informational, } \\
\text { communicative }\end{array}$ \\
\hline Doing home problem research work & Demonstration at the seminar lesson & Cognitive, informational \\
\hline Development of the integrated science project & Presentation, defense & Cognitive, informational \\
\hline
\end{tabular}

- System application in the educational process of the lesson of design and research methods.

- Constructive use of information and communication technology [4].

Ratio of competencies to the types of educational acities and diagnostic forms

\section{From experience}

A few years ago, while reading a book, I came across the wisdom of the ancient Chinese philosophers: "Tell me and I forget. Teach me and I remember. Involve me and I learn." The words impressed me with their simplicity and capacity at the same time. I took this phrase as an exclamation of my student: "I'll do it myself!". This wisdom reflects the main idea of student-centered education - the student is a carrier of individual personal experience, he himself seeks to reveal his own potential given to him by nature. Since then, I have deliberately passed my functions as a teacher on to my students.

One of the most important moments of the lesson is the formulation of educational tasks, setting of goals. I tried to formulate goals together with students before, and now we do it only together. We manage to do this most successfully at the beginning of any topic. Let me give a few examples.

The topic "Interaction of bodies"

I put questions to students:

- Is it necessary to study mechanical phenomena?

- What for?

- Where can we use that?

These are standard questions that can be used in almost every lecture. Listening to the opinions of students, I focus on personally colored examples. The activity of students is enriched with a fundamentally new content, characterized by a focus on the development of students' ability to set goals and reflect their own knowledge.

Topic "Electric phenomena".

Here I suggest students to formulate questions to which they would like to search and find answers. Of the many questions formulated, the students themselves separate those that relate to the physical essence of the phenomenon, its origin, patterns, manifestations and establishment of cause-and-effect relationships. With this technique, I stimulate the formation of a student's cognitive request to the teacher, some of the questions of which I refer to other sources (popular-science literature, Wikipedia).

Almost always there are sources of knowledge among peers, to the subjective experience of which I draw attention. As a result, students formulate learning goals or tasks as freely chosen on the basis of their needs and interests.

Most often, students find out how many hours are devoted to the topic, whether there will be laboratory works and experimental tasks. From class to class, bachelors develop ability to plan their actions and predict results, ability to create a route to the unknown by their own efforts, that is, to learn (to teach themselves). Thus, we together create a situation of the vital need for new knowledge.

Another way to implement the competence approach is the project method.

The project method is a search for a solution to a problem, a problem situation, it is a joint work of a teacher and a student, aimed at finding a solution to a problem that has arisen, a problem situation. This 
method is one of the student-centered technologies, ways of organizing independent activities of students, aimed at solving the problems of an educational project, integrating the problem approach, group methods, reflexive, research and other techniques.

The practical topics "Heat engines", "Heat phenomena", "Electric current in various environments" are studied in the form of mini - projects which allow reducing the time for their study and improving its quality by several times.

Any laboratory work can become a mini - project if we do not conduct under a detailed instruction, behind which the meaning of the work is sometimes lost, but give students only a task for which they themselves should choose equipment, develop a work plan, conduct an experiment on their own and draw a conclusion. With this performance, as a rule, students better understand what they are doing, better absorb the material [5].

Physics classes structured in such a way contribute to the formation of students' over-subject competencies.

I want to write these words again:

"Tell me and I forget. Teach me and I remember. Involve me and I learn." These words were modern in the ancient China and they are priceless in the modern world.

References:

1 Ruzakhodzhaeva, G.A., \& et.al (2015). Sushchnost i soderzhaniie kompetentnostnogo podkhoda [The essence and content of the competence approach]. Education and science: theoretical and meth- odological aspects. Mezhdunarodnaia nauchno-prakticheskaia konferentsiia. - International scientific and practical conference. (pp. 127-130). Moskva [in Russian].

2 Khutorskoy, A.V. (2002). Kliuchevyie kompetentsii i obrazovatelnyie standarty [Key competencies and educational standards]. Eidos: Internet-Journal. Retrieved from: http:/www.eidos.m/journal/2002/0423.htm [in Russian].

3 Aleksandrov, I.V., Afanasieva, A.M., \& Strokina, I.V. (2008). Kompetentnostnyi podkhod i otsenka kachestva yestestvennonauchnoi podgotovki $\mathrm{v}$ inzhenernom obrazovanii [Competence approach and quality assessment of natural science training in engineering education]. School and University: achievements and problems of continuous physical education. Rosiiskaya nauchno-metodicheskaia konferentsiia Russian scientific and methodological conference. (pp. 9-12). Yekaterinburg [in Russian].

4 Ponomarenko, Ye.V. (2013). Analiz sovremennogo sostoianiia metodiki prepodavaniia fiziki $\mathrm{V}$ vysshei shkole [Analysis of the current state of physics teaching methods in higher education: competence approach.]. Mezhdunarodnyi zhurnal eksperimentalnogo obrazovaniia - International journal of experimental education, 10, 207-210 [in Russian].

5 Kasenova, L.G. (2017). Virtualnyi laboratornyi praktikum po fizike dlia distantsionnoi formy obucheniia studentov [Virtual laboratory workshop on physics for distance learning students]. Vestnik Karagandinskogo universiteta - Bulletin of the Karaganda university, 3 (87), 76-81 [in Russian].

\section{ИССЛЕДОВАНИЕ РАСПРЕДЕЛЕНИЯ ЛАЗЕРНОГО ИЗЛУЧЕНИЯ В ДВУХМОДОВОМ} ВОЛОКОННОМ СВЕТОВОДЕ

DOI: 10.31618/ESU.2413-9335.2019.5.62.119
Насиров Т.3.
кандидат физико-математических наук,
домент кафедры лазерных технологий и оптоэлектроники
Ташкентский государственный технический университет имени И. Каримова
Юсупов Д.Б.
доктор физико-математических наук,
Ташкентский государственный технический университет имени И. Каримова
Хожиев Фаррух Анварович
магистрант
Ташкентский государственный технический университет

\section{INVESTIGATION OF DISTRIBUTION OF LASER RADIATION IN THE TWO MODE OPTIC FIBER}

Nasirov T.Z.

doctor of philosophy in physics and mathematics, professor of department laser technologies and optoelectronics

Tashkent State technical University named after I. Karimov

Yusupov D.B.

doctor of science in physics and mathematics, professor of department laser technologies and optoelectronics

Tashkent State technical University named after I. Karimov

Khojiyev Anvar Anvarovich

magister

Tashkent State technical University named after I. Karimov 